List of Contributors

Richard Bragg

Judith Church

Brian F. Cook

Valerie Cumming

Brian Davenport Q.C.

Thomas K. Dreier

Frosso Egoumenidou

Christina Fischauser

Caroline Forder

Manlio Frigo
Faculty of Law, The University, Manchester, M13 9PL, Tel: (061) 2753560 Fax: (061) 2734407

Debevoise \& Plimpton, 875 Third Ave., New York, NY 10022, U.S.A., Tel: (212) 9096000 Fax: (212) 9096836

Keeper, Department of Greek and Roman Antiquities, The British $\mathrm{Mu}$ seum, London, WC1B 3DG, Tel: (071) 6361555 Fax: (071) 3238355

Deputy Director, Museum of London, London Wall, London, EC2Y 5HN, Tel: (071) 6003699 Fax: (071) 6001058

Norton Rose Solicitors, Kempson House, Camomile Street, London, EC3A 7AN, Tel: (071) 2832434 Fax: (071) 5881181

Max-Planck-Institut, Siebertstrabe 3, D-8000 München 80, Germany, Tel: (089) 9246224 Fax: (089) 9246247

Foundation Anastasios G. Leventis, 28 Soufoulis St, Chanteclair Bld., Off. 114, Nicosia, Cyprus, Tel: 02416706 Fax: 02459090

Rechtswissenschaftliches Seminar der Universität Zürich, Centrum Für Internationales Privatrecht, Wiesenstraße 9, CH-8008 Zürich, Tel:257 31 11/12 Fax: 3820285

Privaatrecht, Faculteit der Rechtsgeleerdheid, Rijksuniversitet Limburg, Postbus 616, 6200 MD Maastricht, The Netherlands, Tel: (043) 887777 Fax: (043) 256538

Via Ludovico Da Viadana, 9, 20122 Milano, Italy, Tel: (02) 58303197-206 Fax: (02) 58303206 
Joanna Goyder

Stephen Z. Katz

Paul Kohler

Jonathan Montgomery

Astrid-Maria Müller

Anna-Dorothea Polzer

Anthony Ross

David Saunders

Kurt Siehr

Philip Smith

Ben Ward
European Co-Ordinator, Baker \& McKenzie, Boulevard du Régent 40, 1000 Brussels, Belgium, Tel: $32-2$ 5063611 Fax: 32-2 5116280

Partner, Walsh Micay and Company, $10^{\text {th }}$ Floor Richardson Building, One Lombard Place, Winnipeg, Canada, R3B 3HI, Tel: (204) 9420081 Fax: (204) 9571261

Faculty of Laws, University College London, Bentham House, 4-8 Endsleigh Gardens, London, WC1H OEG, Tel: (071) 3877050 Fax: (071) 3879597

Faculty of Law, University of Southampton, Highfield, Southampton, S09 5NH, Tel: (0703) 592875 Fax: (0703) 593024

c/o Rechtswissenschaftliches Seminar der Universitat Zurich, Centrum Für Internationales Privatrecht, Wiesenstrasse 9, CH-8008 Zurich, Tel: 25731 11/12 Fax: 3820285

Heuking, Kühn, Herold, Kunz,Wojtek, Rechtsanwälte, Wirtschaftsprüfer, Steuerberater, Lindenstraße 37, 6000 Frankfurt a. M. 1, Tel: (069) 975610 Fax: (069) 97561200

4 Verulam Buildings, Gray's Inn, London WC1R 5LW, Tel: (071) 4056114 Fax: (071) 8316112

Griffith University, Brisbane, Australia, Tel: (617) 8757111

Rechtswissenschaftliches Seminar der Universitat Zurich, Centrum Für Internationales Privatrecht, Wiesenstrasse 9, CH-8008 Zurich, Tel: 25731 11/12 Fax: 3820285

Department of Sociology, 405 Hilgard Ave., University of California, Los Angeles, CA 90024 1551, U.S.A.

c/o Professor N E Palmer, Faculty of Laws, University College London, Bentham House, 4-8 Endsleigh Gardens, London, WC1H OEG, Tel: (071) 3807326 Fax: (071) 3879597 


\section{Projects in Progress}

163 The Cyprus Department of Antiquities and the Protection of Monuments of the Recent Past Frosso Egoumenidou

\section{Book Reviews}

171 Raymonde Moulin L'artiste, l'institution et le marché

Thomas K. Dreier

$176 \mathrm{C}$. Weyergraf-Serra and M. Buskirk (eds.) The Destruction of 'Tilted Arc': Documents David Saunders

183 Hermann J. Knott Der Anspruch auf Herausgabe gestohlenen und illegal exportierten Kulturguts [The Right to Claim Restoration of Stolen and Illegally Exported Cultural Goods] Christina Fischhauser

185 Rudolf Kleeberg and Wolfgang Eberl Kulturgüter in Privatbesitz. Handbuch für das Denkmal - und Steuerrecht [Cultural Objects in Private Possession. Handbook on the Law of Monuments and their Taxation] Kurt Siehr

186 Janet Wolff and John Seed (eds.) The Culture of Capital: art power and the nineteenth-century middle class Philip Smith

\section{Conference Reports}

189 International Conference on the Theme 'Eredità Contestata?'

Rome 29-30 April 1991 Brian F. Cook

196 The Legal Aspects of International Trade in Art The Madrid Symposium 12-14 February 1992 Astrid-Maria Müller

202 Sixth Annual Conference of the Institute of Field Archaeologists Birmingham 6-8 April 1992

Brian F. Cook

203 The Second International Art, Antique and Architectural Theft Conference held by Trace Magazine and the Georgian Group, London 8-11 June 1992

Ben Ward

\section{Preview}

In our fourth issue we plan to publish articles on rights to historic wrecks and wreckage, the operation of the law of treasure trove and attribution and the claim to objectivity. The second of these articles will include an examination of new law reform proposals in England. In addition to our normal range of casenotes and Chronicles, we shall feature a report on the Museums and Galleries Act 1992. Contributors to the fourth issue will include Robert Paterson, Sarah Dromgoole, Nicholas Gaskell, John Murdoch and Caroline Forder. 


\section{Contents}

No. $1 \cdot$ Vol. $2 \cdot 1993$

7 Editorial Norman Palmer

\section{Articles}

11 Penal Protection of Cultural Property: The Canadian Approach Stephen Z. Katz

\section{Market Overt} Brian Davenport Q.C. and Anthony Ross

47 Evolving U.S. Case Law on Cuiltural Property Disputes Judith Church

73 The Proposed EEC Council Directive on the Return of Unlawfully Exported Cultural Objects Manlio Frigo

\section{Essay}

81 Some Observations on a Recent Acquisition Valerie Cumming

\section{Chronicles}

\section{Case Notes}

105 The Responsibility of Church and State for Preserving Cultural Property Jonathan Montgomery

111 A Clock in Court: East German Export of
Cultural Property Considered by West German Courts Anna-Dorothea Polzer

117 The Bredius Museum Case: Public Interest and Private International Law Caroline Forder

127 Trade Descriptions and the Art World Richard Bragg

133 Colonel Sanders, Finding and Possessory Title Paul Kohler

\section{Treaties and EC Matters}

147. European Community Free Movement of Cultural Goods and European Community Law Part III: Two New Legislative Proposals Joanna Goyder

\section{Documents}

157 German Archaeology Institute The Berlin Declaration 1988

159 The National Council for Metal Detecting Code of Conduct

160 Draft Licence for Landowners Wishing to Allow Metal Detecting on Their Land 